\title{
THE CYTOLOGY OF
}

THE PARATHYROID GLANDS OF THE RAT AFTER

BILATERAL NEPHRECTOMY, ADMINISTRATION

OF PARATHYROID HORMONE AND

HYPOPHYSECTOMY ${ }^{1,2}$

RICHARD J. WEYMOUTH

Department of Anatomy, University of Michigan Medical School, Ann Arbor, Michigan

FIFTEEN FIGURES

No technical method is available which will demonstrate parathyroid hormone or its precursors within the cells which secrete it. In the parathyroid glands of single species, several investigators have described intracellular materials which were regarded as being secretory in nature (Weymouth and Baker, '54). However, their conclusions have not been accepted generally. More recently, Weymouth and Baker ('54) observed intracellular silver granules in the parathyroids of seven species after staining with the Protargol method. Some indication of the secretory significance of these granules may be gained by determining the manner in which they change when the secretory rate of the gland is altered by experimental means. The parathyroids may be made hyperactive by creating a state of renal insufficiency (Selye, ' 42 ; Ingalls et al., '43) or hypoactive by the administration of parathyroid hormone (McJunkin and Tweedy, '32; Hanssler, '53). Only DeRobertis ('40, '41) and Baker ('45) have studied para-

${ }^{1}$ An abridgment of a thesis submitted in partial fulfillment of the requirements for the degree of Doctor of Philosophy in the University of Michigan.

'Supported in part by research grants to Dr. B. L. Baker from the National Institutes of Health, Public Health Service [A-131(C3)] and from the Upjohn Company. 
thyroids by cytological methods under these experimental conditions.

In addition, the functional relationship of the hypophysis and parathyroids is not clear. Although the secretion of a pituitary parathyrotropic hormone has been postulated, adequate proof for its existence is not available (Baker, '42). The purpose of the following investigation was to determine the manner in which the silver granules and cytoplasmic basophilia respond to bilateral nephrectomy, administration of parathyroid hormone and hypophysectomy.

\section{MATERIALS AND METHODS}

Rats of the Sprague-Dawley strain were used. They were fed Purina Dog Chow with weekly supplements of greens and citrus fruits. Except in the experiments which were terminated in 24 hours or less, the control animals were pair-fed against the operated or hormone-treated rats.

The parathyroids were stimulated by bilateral nephrectomy with a post-operative period of $60-72$ hours being allowed. The secretory activity of the parathyroid glands was decelerated by subcutaneous injection of bovine parathyroid extract ${ }^{3}$ into female rats. Details of the experiments are summarized in table 1.

The effectiveness of bilateral nephrectomy and parathyroid hormone administration in inducing parathyroid hyperactivity and hypoactivity, respectively, was assessed by counting the number of nuclei in selected fields as an indirect indication of change in cellular size and by determining the serum calcium level (table 1) according to the procedure of Wang ('35). The completeness of hypophysectomy (table 1) was proven by microscopic examination of complete serial sections of the pituitary region.

One parathyroid gland from each animal with some attached thyroid tissue was fixed in a solution containing

${ }^{3}$ We express our appreciation to Dr. G. W. Irwin of Eli Lilly and Company for the parathyroid extract which assayed at not less than 100 U.S.P. units $/ \mathrm{cm}^{3}$. 
formaldehyde, glacial acetic acid and ethyl alcohol $(1: 1: 18)$ (FAA). After embedding in paraffin, the glands were sectioned at $4 \mu$. Some were stained with the Bodian ('36) Protargol method, others with $0.2 \%$ methylene blue in a citric acid-phosphate buffer, $\mathrm{pH} 6.8$, or with toluidine blue. $\mathrm{A}$ few sections were digested in a $0.01 \%$ solution of ribonuclease

TABLE 1

Summary of experimental conditions

\begin{tabular}{|c|c|c|c|c|c|c|c|c|}
\hline & \multirow{2}{*}{ EXPERIMENT } & \multirow{2}{*}{$\begin{array}{c}\text { No. } \\
\text { RATS }\end{array}$} & \multicolumn{3}{|c|}{ MEAN BODY WT. } & \multirow{2}{*}{$\operatorname{sex}$} & \multirow{2}{*}{$\begin{array}{l}\text { TOTAL } \\
\text { DOSAGE }\end{array}$} & \multirow{2}{*}{$\begin{array}{l}\text { DURATION } \\
\text { OF EXP. }\end{array}$} \\
\hline & & & \multicolumn{2}{|c|}{ Initial } & Final & & & \\
\hline & & & \multicolumn{2}{|l|}{$g m$} & $g m$ & & unit 1 & \\
\hline \multirow[t]{2}{*}{1.} & Nephrectomy & 40 & \multirow{2}{*}{\multicolumn{2}{|c|}{$\begin{array}{l}395 \pm 54^{2} \\
376 \pm 34\end{array}$}} & $393 \pm 62$ & \multirow[t]{2}{*}{$\delta$} & & $60-$ \\
\hline & Control & 35 & & & $347 \pm 46$ & & & 72 hours \\
\hline \multicolumn{9}{|c|}{$\begin{array}{l}\text { 2. Parathyroid } \\
\text { hormone ad- } \\
\text { ministration }\end{array}$} \\
\hline & \multicolumn{8}{|l|}{ a. Parathyroid } \\
\hline & hormone & 9 & $159 \pm$ & 6 & $158 \pm 7$ & q & $700^{3}$ & 18 hours \\
\hline & Control & 7 & $161 \pm$ & 6 & $162 \pm 7$ & & & \\
\hline & \multicolumn{8}{|l|}{ b. Parathyroid } \\
\hline & hormone & 19 & $166 \pm$ & $1^{4}$ & $163 \pm 2$ & 우 & $150^{5}$ & 36 hours \\
\hline & Control & 19 & $167 \pm$ & 4 & $165 \pm 4$ & & & \\
\hline & \multicolumn{8}{|l|}{ c. Parathyroid } \\
\hline & hormone & 4 & $160 \pm$ & 9 & $161 \pm 6$ & $q$ & $300^{5}$ & 101 hours \\
\hline & Control & 5 & $166 \pm$ & 7 & $161 \pm 8$ & & & \\
\hline & \multicolumn{8}{|l|}{ d. Parathyroid } \\
\hline & hormone & 7 & $67 \pm$ & 4 & $75 \pm 5$ & $q$ & $111-$ & 5 days \\
\hline & Control & 7 & $62 \pm$ & 2 & $64 \pm 4$ & & $129^{\circ}$ & \\
\hline \multirow[t]{2}{*}{3.} & Hypophysectomy & 9 & $178 \pm$ & 7 & $163 \pm 16$ & q & & 30 days \\
\hline & Control & 9 & $178 \pm$ & 3 & $167 \pm 6$ & & & \\
\hline
\end{tabular}

${ }^{1}$ U.S.P.

${ }^{2}$ Standard deviation.

${ }^{3}$ The hormone was injected in doses of 350 units at 5:00 P.M. and 10:00 P.M. with autopsy during the morning of the second day.

${ }^{4}$ Autopsy of 5 rats.

${ }^{5}$ The hormone was injected in doses of 30 units at 9:00 A.M., 12:00, and 9:00 P.M. Autopsies were performed about 5 hours after the last injection.

${ }^{6}$ The hormone was injected in doses of approximately 13.0 units at 9:00 A.M. and $9: 00$ P.M. 
prior to staining with methylene blue or toluidine blue in order to demonstrate the presence of ribonucleic acid.

\section{OBSERVATIONS}

\section{The normal parathyroid}

Argyrophilia. Silver granules were observed in practically all parenchymal cells (fig. 1). They varied considerably in color and size, some reaching a diameter of 0.7 to $1.0 \mu$. They were most concentrated in the region of the Golgi apparatus. None were observed in the connective tissue trabeculae which separated the clusters of parenchymal cells (fig. 10). The appearance of these granules was not dependent upon the presence of ribonucleic acid since prior incubation with ribonuclease or buffer alone did not prevent subsequent staining with the Protargol method (figs. 8 and 9).

Basophilia. After staining with methylene blue or toluidine blue, a fine basophilic reticulum was present throughout the cytoplasm of the parenchymal cells (fig. 12). Associated with the Golgi region were compact bodies of a deep purple color. Nucleoli were prominent and the chromatin was fine and dispersed throughout the nucleus. The ribonucleic acid composition of the basophilic material in the cytoplasm and nucleolus was demonstrated by its complete removal during digestion in a solution of ribonuclease. Digestion in the buffer solution did not alter subsequent basophilic staining.

\section{The effect of nephrectomy}

Several criteria indicated that a state of accelerated secretory activity by the parathyroids was created successfully by bilateral nephrectomy. The glands were hypertrophied. The serum calcium level was decreased (table 2), this change being an incitant to parathyroid secretion. The parenchymal cells were enlarged as indicated by a significant reduction in the number of nuclei counted per unit area (table 2). There 
was a marked increase in the frequency of mitotic figures and the nucleoli were enlarged.

Argyrophilia. A significant depletion of silver granules was not induced by bilateral nephrectomy, although they were more dispersed throughout the hypertrophied cells (figs. 1

TABLE 2

The effect of experimental treatment on serum calcium and the concentration of parenchymal cell nuclei

\begin{tabular}{|c|c|c|c|c|c|c|c|}
\hline & \multirow{2}{*}{ DXPERIMENT } & \multirow{2}{*}{$\begin{array}{l}\text { No. } \\
\text { RATS }\end{array}$} & \multirow{2}{*}{$\begin{array}{l}\text { MRAN NO. } \\
\text { NUCLEI/ } \\
\text { UNIT AREA }\end{array}$} & \multirow{2}{*}{$P^{1}$} & \multirow{2}{*}{$\begin{array}{l}\text { No. } \\
\text { RATS }\end{array}$} & \multicolumn{2}{|c|}{ MEAN SHRUM } \\
\hline & & & & & & $\mathrm{Ca}$ & $\mathbf{P}$ \\
\hline & & & & & & $\underset{\mathrm{mg} / 100}{\mathrm{~cm}^{3}}$ & \\
\hline \multirow[t]{2}{*}{1.} & Nephrectomy & 9 & $181 \pm 5.7^{2}$ & $<.001$ & 10 & $8.16 \pm 0.2$ & .001 \\
\hline & Control & 9 & $255 \pm 6.8$ & & 8 & $10.80 \pm 0.9$ & \\
\hline \multirow[t]{13}{*}{2.} & $\begin{array}{l}\text { Parathyroid } \\
\text { hormone ad- } \\
\text { ministration }\end{array}$ & & & & & & \\
\hline & a. Parathyroid & & & & & & \\
\hline & hormone & 5 & $275 \pm 4.3$ & $<.01$ & & & \\
\hline & Control & 4 & $257 \pm 6.4$ & & & & \\
\hline & b. Parathyroid & & & & & & \\
\hline & hormone & 6 & $259 \pm 4.1^{3}$ & $>.05$ & 3 & $12.90 \pm 0.2$ & $<.001$ \\
\hline & Control & 5 & $257 \pm 2.7$ & & 3 & $10.60 \pm 0.2$ & \\
\hline & c. Parathyroid & & & & & & \\
\hline & hormone & & & & 4 & $13.40 \pm 0.7$ & $<.001$ \\
\hline & Control & & & & 5 & $10.90 \pm 0.2$ & \\
\hline & d. Parathyroid & & & & & & \\
\hline & hormone & 5 & $274 \pm 3.7$ & $<.001$ & & & \\
\hline & Control & 4 & $246 \pm 4.6$ & & & & \\
\hline \multirow[t]{2}{*}{3.} & Hypophysectomy & 7 & $293 \pm 5.8$ & $<.001$ & & & \\
\hline & Control & 7 & $258 \pm 5.4$ & & & & \\
\hline
\end{tabular}

${ }^{1}$ Student-Fisher $t$; if variance ratio was significantly high, the Welch formula was used:

${ }^{2}$ Standard deviation.

$$
t=\frac{\overline{\mathrm{X}_{1}}-\overline{\mathrm{X}}_{2}}{\frac{\mathrm{L}_{1}}{\mathrm{~N}_{1}^{2}\left(\mathrm{~N}_{1}-1\right)} \frac{\mathrm{L}_{2}}{\mathrm{~N}_{2}{ }^{2}\left(\mathrm{~N}_{2}-1\right)}}
$$

${ }^{3}$ These figures include the animals injected with 150 and 300 units of parathyroid hormone. 
and 2). Juxtanuclear aggregates of granules were less frequent than in control rats. On the average, the granules were finer than those of control rats. They were often lined up along the cell membrane, in particular the portion which was proximal to the vascular supply. Large argyrophilic bodies measuring $1.5-2.0 \mu$ in diameter appeared in the connective tissue of all nephrectomized animals, being most numerous in the vicinity of blood vessels (fig. 11). Silver granules were never observed in the lumina of blood vessels and only infrequently appeared to be located in the cytoplasm of the endothelial cells lining these vessels. Their demonstration was not prevented by prior digestion with ribonuclease. $\mathrm{Nu}$ cleoli were increased in size.

Basophilia. The intensity of staining and the amount of basophilic material were increased, this change being greatest in the cells which were most hypertrophied. The deeply stained masses which were characteristic of the periphery of the Golgi region in control animals were expanded into an extensive, coarse reticulum, separated from the nucleus by the enlarged Golgi body (figs. 12 and 13). Fine, more lightly stained threads were also present in increased quantity in the enlarged cells. Digestion in ribonuclease destroyed the cytoplasmic basophilia, demonstrating its dependence on the presence of ribonucleic acid.

\section{The effect of parathyroid hormone administration}

Low dosage. The administration of parathyroid hormone at the low doses (150 and 300 units over 36 or 101 hours) (groups $2 \mathrm{~b}$ and $2 \mathrm{c}$, table 1 ) elevated the level of serum calcium in group $2 \mathrm{~b}$ (table 2) but did not reduce the size of parenchymal cells. This was shown by the absence of a change in the number of nuclei counted per unit area (group $2 b$, table 2 ). Also, no modification occurred in the staining intensity, form or number of the silver granules. At a dosage of 150 units of parathyroid hormone over 36 hours, no reduction in basophila occurred. However, a slight decrease occurred in the 
parenchymal cells of the animals which received 300 units of parathyroid hormone for 101 hours.

Administration of parathyroid hormone at a low dosage over a longer period of time (group $2 \mathrm{~d}$, table 1) produced evidence of suppressed secretory activity. Parenchymal cells were smaller as demonstrated by the higher mean nuclear counts (group $2 \mathrm{~d}$, table 2). Nucleoli were smaller and mitotic figures, fewer in number. An increase in concentration of silver granules was striking (figs. 1 and 4), this change being most marked in the Golgi region distal to the connective tissue trabeculae. This response involved most of the parenchymal cells. Cytoplasmic basophilic was decreased (fig. 14).

High dosage. The injection of a massive dose of parathyroid hormone (group 2a, table 1) reduced cellular size as shown by an increase in the mean number of nuclei counted per unit area (table 2). The nucleoli were somewhat smaller and mitotic figures seemed to be less frequent.

The number of silver granules was increased markedly within the parenchymal cells. In some cases this change was limited to isolated cells (fig. 3), while more often it was characteristic of most parenchymal cells (fig. 5), with the greatest concentration being in the Golgi region. No silver granules were observed in the connective tissue of the gland.

Cytoplasmic basophilia was reduced in the parenchymal cells in proportion to the reduction in cellular size, with none being observed in some. The nucleoli of these cells were somewhat smaller in size as compared with those of control glands.

\section{The effects of hypophysectomy}

The parenchymal cells were decreased in size following hypophysectomy as was demonstrated by the number of nuclei per unit area. The mean number in the controls was $258 \pm 5.4$ as compared with $293 \pm 5.8$ for hypophysectomized rats (experiment 3 , table 2 ).

In the sections of parathyroids removed from three of 9 hypophysectomized rats a reduction in silver granules was 
observed (figs. 6 and 7). However, the silver granules in the parathyroids of the other hypophysectomized animals were not significantly different from those of their controls. No granules were found in the connective tissue. After staining with silver or basic dyes, the chromatin was more coarsely arranged than in glands of the control animals and was indistinguishable from the nucleoli. Accompanying the reduction in cellular size was a mild and irregular diminution in the quantity of basophilic substance in the cytoplasm (figs. 12 and 15).

\section{DISCUSSION}

The functional significance of the silver granules remains unknown. The increased concentration of granules when secretory activity was suppressed by administration of parathyroid hormone, might be interpreted to support the hypothesis that they represent stored hormone or its precursor. On the other hand, their failure to change more significantly when the gland was stimulated is not in accord with this concept. Hyperactivity of the parathyroid glandular cells is associated with an augmentation in the quantity of cytoplasmic ribonucleic acid as shown by the increased intensity of basophilia and hypoactivity, with a decrease. This is significant because parathyroid hormone appears to be a protein (Ross and Wood, '42) and ribonucleic acid is involved in protein synthesis (Greenstein, '44).

Pituitary-parathyroid relationship. Although a reduction in size of the parenchymal cells occurred regularly after hypophysectomy, alteration in the quantity of silver granules and cytoplasmic ribonucleic acid was so inconsistent that this evidence could not be utilized in support of the hypothesis that the pituitary gland exerts direct control over the parathyroids. In the case of the other clearly proven tropic factors of the anterior hypophysis, i.e., thyrotropin, corticotropin and gonadotropin, their absence induces regular and clear-cut histological responses in the target organs. 


\section{ACKNOWI_EDGMENT}

I should like to express sincere appreciation to Dr. Burton L. Baker for his direction of this investigation.

\section{SUMMARY}

Stimulation of the parathyroid glands by bilateral nephrectomy failed to cause a significant depletion of silver granules from the parenchymal cells but large argyrophilic bodies accumulated in the stroma. Cytoplasmic ribonucleic acid, as revealed by basic stains, was increased.

Suppression of secretory activity by administration of parathyroid hormone induced an increase in the concentration of intracellular silver granules and a depletion of cytoplasmic ribonucleic acid. One cannot conclude on the basis of this evidence that the silver granules represent stored parathyroid hormone since greater depletion might have been expected in the hypersecretory state. Cytological alterations after hypophysectomy were variable and did not support the hypothesis that the pituitary gland secretes a parathyrotropic hormone.

\section{LITERATURE CITED}

BAKER, B. L. 1942 A study of the parathyroid glands of the normal and hypophysectomized monkey (Macaca mulatta). Anat. Rec., 83: 47-74. 1945 The structural response of the parathyroid glands to ureteral ligation or bilateral nephreetomy. Anat. Ree., 93: 125-144.

Bontas, D. 1936 A new method for staining nerve fibers and nerve endings in mounted paraffin sections. Anat. Rec., 65: 89-98.

DeRoBeRTIs, E. 1940 The cytology of the parathyroid gland of rats injected with parathyroid extract. Anat. Ree., $78: 473-496$.

1941 The cytology of the parathyroid and thyroid glands of rats with experimental rickets. Anat. Rec., 79: 417-434.

Greenstein, J. P. 1944 Nucleoproteins. Adv. in Prot. Chem., 1: 209-287.

Hanssuer, H. 1953 Experimentelle Untersuchungen über die Beziehungen der Nebensehilddrüsenmorphologie und Funktion zur Vitamin D-Wirkung. Zeitschr. ges. exp. Med., 97: 209-227.

Ingalis, T. H., G. A. Donaldon and F. Albright 1943 The locus of action of the parathyroid hormone: Experimental studies with parathyroid extract on normal and nephrectomized rats. J. Clin. Invest., 28: $603-608$. 
MCJunkin, F. A., AND W. R. Tweedy 1932 The parathyroid hormone. Its regulatory action on the parathyroid glands and toxic action on the tissues of the rat. Arch. Path., 14: 649-659.

Ross, W. F., AND T. R. Wood 1942 The partial purification and some observations on the nature of the parathyroid hormone. J. Biol. Chem., 146: 49-58.

Selye, H. 1942 Mechanism of parathyroid hormone action. Arch. Path., 34: $625-632$.

WANG, C. C. 1935 Improvement in the methods for calcium determination in biological material. J. Biol. Chem., 111: 443-453.

WEYMouT:H, R. J., AND B. L. BAKER 1954 The presence of argyrophilic granules in the parenchymal cells of the parathyroid gland. Anat. Rec., 119: $519-528$. 


\section{PLATES}




\section{PLATE 1}

EXPLANATYON OF HIGURES

The preparations shown in figures $1-4$ were fixed in FAA and stained witl Protargol. $\times 1360.4 \mu$.

1. Control animal for rat illustrated in figure 2, The silver granules vary in size and intensity of staining. They are dispersed throughout the cytoplasm but tend to aceumulate in the Golgi region. The largest granules are about $0.7 \mu$ in diameter (arrow).

2 Sixty-six hours after nephrectomy. The cells, nuclei and nucleoli are hypertrophied. The fine brown and black granules remain numerous and are dispersed throughout the cytoplasm. They tend to line up along cellular membranes. The larger intracellular granules are excedingly rare as compared with figure 1.

3 Parathyroid hormone administration, 700 units, adult female (group $2 a$, table 1). Two cells are shown in which the cytoplasm is engorged with silver granules. Since the granules were similar in the control animals of all experiments, comparison is made with figure 1.

4 Parathyroid hormone administration, 112 units over 5 days, young fomale (group 2d, table 1). The cells show an increase in concentration of silver granules which is especially marked in the region of the Golgi apparatus. The 4 cells on the right illustrate the typical polarity of the parenchymal cells, the Golgi region being loeated on the side of the nucleus away from the connective tissue, which is at the right. 

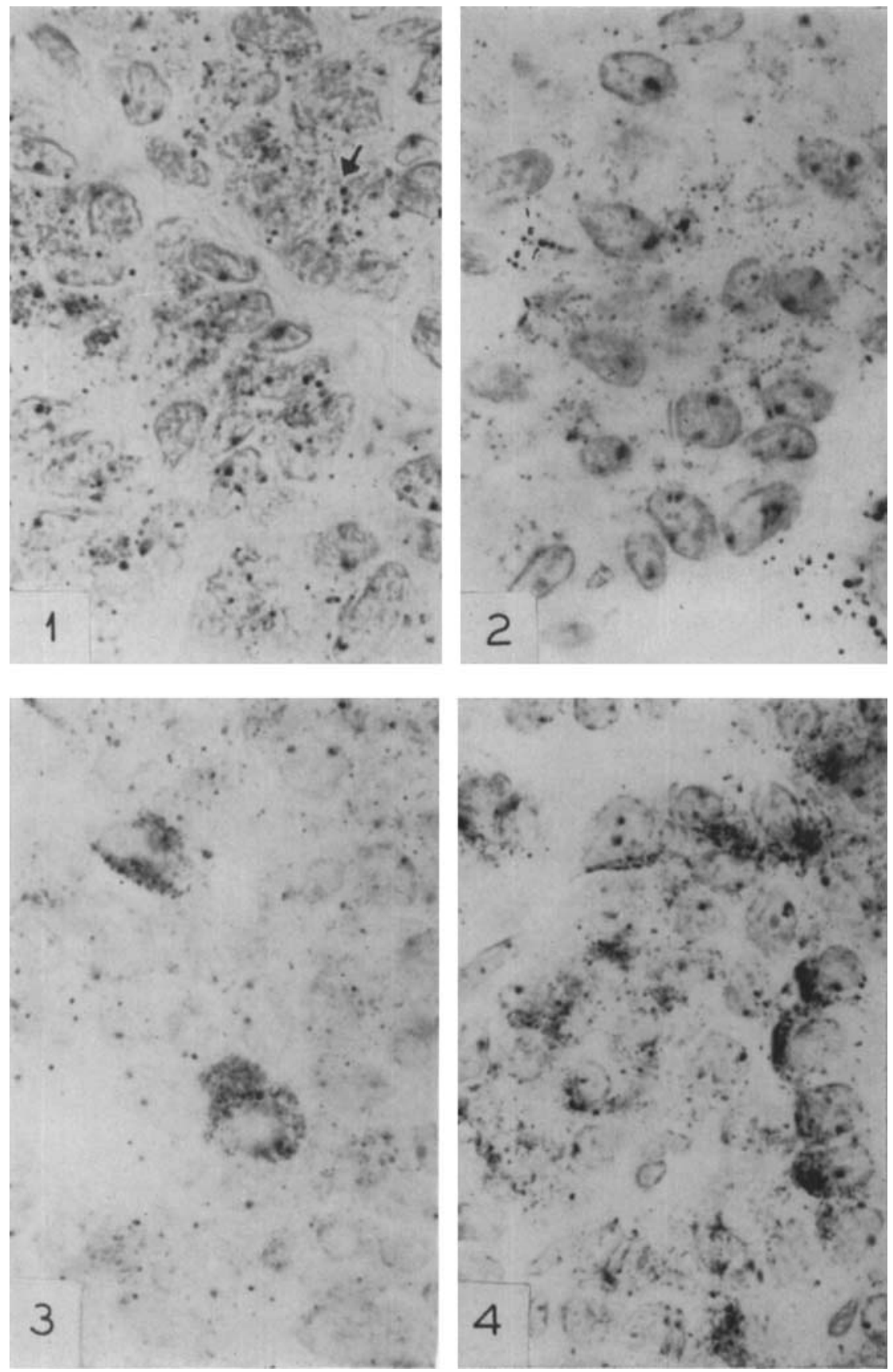


\section{PLATE 2}

EXPLANATION OF FIGURES

The preparations shown in figures 5-7 were fixed in FAA and stained with Protargol. $\times 1360.4 \mu$.

5 Parathyroid hormone administration, 700 units, adult female (group 2a, table 1). As compared with figure 1, the cells are smaller and intracellular granules are more concentrated. The connective tissue contains no granules.

6 Control animal for rat illustrated in figure 7 . The granules are similar in staining intensity, size and arrangement to those shown in figure 1.

7 Thirty days after hypophysectomy. Cells and nuclei are smaller. Silver granules are reduced in number. This rat was affected much more severely thain most other cases.

8 Control animal from a nephrectomy experiment. Incubated in citric acidphosphate buffer, $\mathrm{pH} 6.8$ for one-half hour at $37^{\circ} \mathrm{C}$. prior to staining with Protargol. The silver granules are as numerous as in figure 1 . $\times 1360.4 \mu$.

9 Same gland as that shown in figure 8. Incubated in a $0.01 \%$ solution of ribonuelease in a citric acid-phosphate buffer, $\mathrm{pH} 6.8$, for one-half hour at $37^{\circ} \mathrm{C}$. prior to staining with Protargol. The granules are unchanged as compared with those in figure $8 . \times 1360.4 \mu$. 

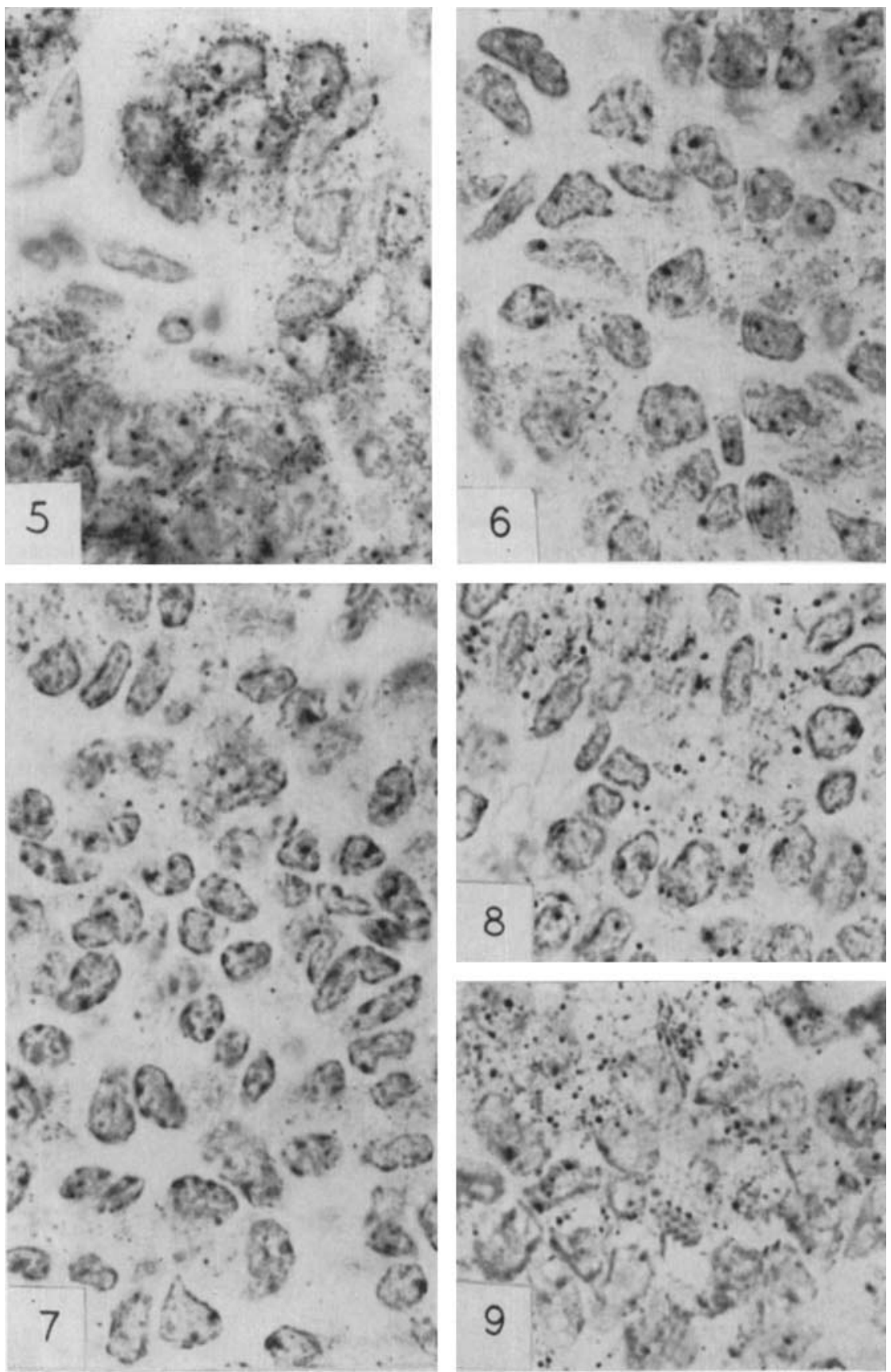
PLATE 3

EXPLANATION OF FIGURES

The preparations shown in figures 10 and 11 were fixed in FAA, stained with Protargol and aniline blue. $\times 1120.4 \mu$. The preparations shown in figures 12-15 were fixed in FAA and stained with toluidine blue $\times 1360.4 \mu$.

10 Control animal for that shown in figure 11. The silver granules arf, present only in the parenchymal eclls and none in the comnective tissue or sinusoid.

11 Sixty-seven hours after nephreetomy. Large argyrophilic bodies are distributed throughout the connective tissue surrounding the vaseular channels. A venule is at the lower left.

12 Since the parathyroid glands of the control animals did not differ significantly in the experiments involving nephrectomy, parathyroid lormone administrattion or hypophysectomy, this illustration is used for comparison with figures 13, 14, and 15. Certain eclls (arrow) show a dense, deeply-stained hasonhilie mass at the periphery of the Colgi area. More lightly stainct basophilie material is dispersed throughout the cytoplasm as fine particles, appearing gray in the photograph.

13 Sixty-four hours after nephrectomy. The deeply stained basophilie material (arrow) is spread out at the periphery of the enlarged Golgi area into a coarse reticulum. Basophilie substance is present throughout the cytoplasm of the enlarged cells.

14 Parathyroid hormone administration, 125 units of hormone over 5 days (group 2d, table 1). Cytoplasmic basophilia is decreased.

15 Thirty days after hypophysectomy. As compared with figure 12 , eytoplasmie basophilia is reduced. 

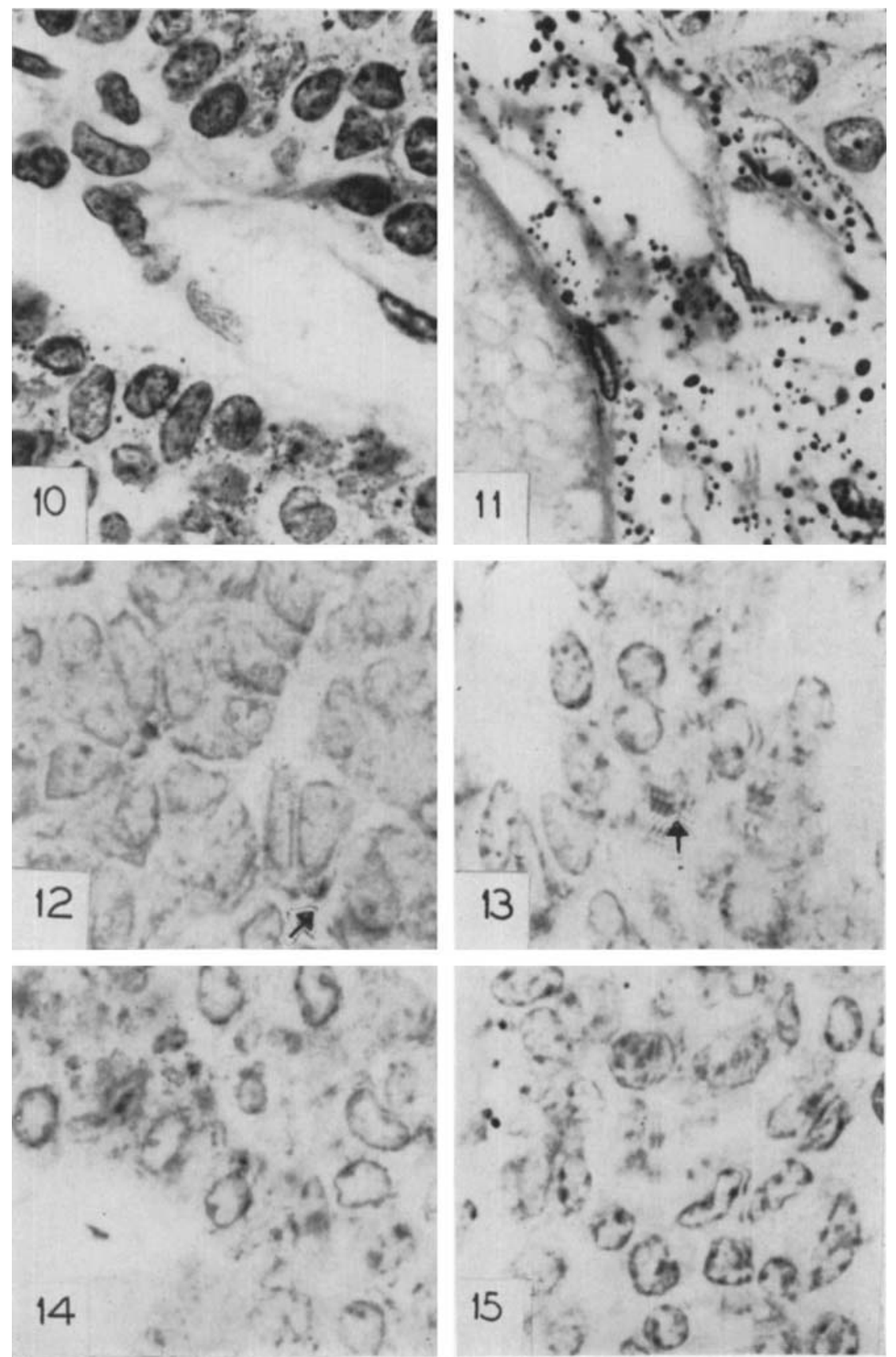